Brazilian Journal of Poultry Science Revista Brasileira de Ciência Avícola

\title{
Broiler Litter Reutilization Applying Different Composting Concepts
}

Technical Note

\section{Author(s)}

Sonoda $\mathrm{LT}^{1}$

Moura, DJ2

Bueno, $\mathrm{LGF}^{3}$

Cordeiro, $\mathrm{DC}^{4}$

Mendes, AS $^{5}$
1 State University of Campinas

2 Professor, Agricultural Engineering College. State University of Campinas

3 Professor, Animal Science College - UnespDracena

${ }^{4}$ Undergraduate student, Agricultural Engineering College. State University of Campinas

5 Professor, Agronomy College. Technological Federal University of Paraná

\section{Mail Adress}

Daniella Jorge de Moura, Departamento de Construções Rurais e Ambiência, Feagri/ UNICAMP, Av. Candido Rondon, 501, Barão Geraldo - Campinas /SP, Cidade Universitária Zeferino Vaz, CEP 13083-875.

E-mail: daniella.moura@feagri.unicamp.br

\section{Geywords}

Fermentation, nitrogen, waste treatment, broiler.
Submitted: March/2011

Approved: October/2012

\begin{abstract}
Broiler litter reutilization consists in using the same bedding material to cover the house floor for several broiler flocks. This requires the litter to be treated in order to reduce the amount of microorganisms, according to international recommendations. The aim of this study was to evaluate two methods of broiler litter fermentation based on composting concepts and their effect on litter and the air quality during fermentation in small-scale broiler houses. The experiment was carried out in the Environmental Laboratory I of the School of Agricultural Engineering of the State University of Campinas, utilizing six smallscale houses. Litter from the same grow-out (one, two or three) was distributed in two experimental houses, where it was either piled or spread. Before beginning the treatment, six litter samples were collected from each house and analyzed for total nitrogen content, humidity, $\mathrm{pH}$ and microbial counts. Litter humidity, gas emission $\left(\mathrm{NH}_{3}\right.$ and $\left.\mathrm{CO}_{2}\right)$, environmental temperature, air relative humidity, and air velocity were determined during and after composting. Bacterial population, especially of Salmonella sp, was higher when the litter was piled compared with spread litter. However, fungi population showed a different pattern, decreasing after composting. Nevertheless, both treatments were not able to significantly reduce bacterial counts, specifically Salmonella sp, when the population before and after fermentation were compared.
\end{abstract}

\section{INTRODUCTION}

The poultry industry is one of the fastest growing sectors of global agribusiness because of the increasing demand for animal protein, including meat and eggs. However, one of the main challenges of modern poultry production is the disposal of waste, particularly of broiler litter (Bolan et al., 2010). At the same time, the poultry industry also faces litter availability problems because of the increasing demand. Therefore, different substrate types and qualities available in the market need to be used (Bigili et al., 2009).

Litter is used to provide comfort to the birds and to maintain carcass quality, as it reduces the incidence of breast and footpad lesions, as well of lesions in other less commercially important parts (Oliveira et al., 2002).

According to Kelleher et al. (2002), litter and waste predominantly consist of water, carbon $(\mathrm{C})$, nitrogen $(\mathrm{N})$ and phosphorus $(\mathrm{P})$, and lower levels of chlorine $(\mathrm{Cl})$, calcium $(\mathrm{Ca})$, magnesium $(\mathrm{Mg})$, sodium $(\mathrm{Na})$, manganese $(\mathrm{Mn})$, iron $(\mathrm{Fe})$, copper $(\mathrm{Cu})$, zinc $(\mathrm{Zn})$, and arsenic (As). These levels vary among broiler houses and regions, depending on the substrate, number of flocks reared, drinking systems, hygiene status, cleaning method, and storage (Edwards \& Daniel, 1992; Jacob et al., 1997; Dao \& Zhang, 2007). 
Due to economic reasons, litter is often reutilized for several flocks. However, excessive reutilization impairs house disinfection, worsening the microbiological quality of the production system (Walter, 2000). This may increase the prevalence of pathogens, such as Salmonella sp., in the environment (Chernaki-Leffer et al., 2002), and therefore, management practices that reduce broiler house contamination need to be developed. For instance, Abreu et al. (2011) evaluated different litter substrates (soybean stubble and rice husks) and two ventilation systems (fixed and oscillating) and observed a reduction in enterobacteria levels in the litter.

Some methods to reduce the microbiological load in reused litter are mentioned in literature, such as anaerobic digestion, composting (aerobic fermentation) and direct combustion (Kelleher et al., 2002). In a review on litter utilization, Turnell et al. (2007) define composting as the collapse of a microbial population contained in the organic matter of the substrate in a thermophilic phase, which is the phase when the temperature of the pile is between 45 and $70^{\circ} \mathrm{C}$ (Miller, 1996; Sundberg et al., 2004). Those authors also stress that composting systems seem to be interesting for the treatment of broiler farming waste because it reduces waste volume. During composting, organic material is broken down, which improves waste storage characteristics and management, reducing its volume, weight, pathogenic load, and undesirable odors, as well as stabilizing nutrients and organic matter (Tiquia \& Tam, 1998; Tiquia et al., 2000). However, this requires providing optimal conditions for microbial growth, such as temperature, aeration, humidity, nutrients, and optimal carbon to nitrogen ratio (Costa et al., 2005). However, the trade and use of composted broiler litter is still under discussion, due to health and environmental reasons (Peigne \& Giradin, 2004; Tiquia \& Tam, 2002).

In the study of Kwak et al. (2005) on the effect of composting of broiler litter by piling (1.2m high) in the elimination of Escherichia coli, Salmonella enteritidis and Shigella sonnei, it was observed that these pathogens were eliminated between day 2 and 4 of composting, and that the highest temperature recorded was $62^{\circ} \mathrm{C}$ on day 6 of fermentation.

On the other hand, when animal waste is composted, nitrogen is lost due to ammonia volatilization, but this negative effect may be minimized by controlling the humidity and the $\mathrm{pH}$ of the substrate used for composting (Kelleher et al., 2002; Tiquia \& Tam, 2002; Delaune et al., 2004). Another potential problem of composting systems is the emission of greenhouse gases which may contribute for global warming and acid rain (Ginting et al., 2003; HAO et al., 2004; Peigne \& Girardin, 2004; Sharpe et al., 2004).

Therefore, we hypothesized that the use of adequate broiler litter fermentation methodologies may improve its quality and allow it to be reutilized. The objective of this study was to evaluate the effects of two composting methodologies on litter and air quality of broiler houses.

\section{MATERIALS AND METHODS}

The experiment was carried out at the Environment Laboratory I of the School of Agriculture Engineering of the State University of Campinas on June 10-22, 2010.

Six reduced-scale broiler houses were used to reproduce the litter fermentation treatments. Houses were built in the east-west direction and were $3.0 \mathrm{~m}$ long, $1.4 \mathrm{~m}$ wide, and $1.1 \mathrm{~m}$ high, made of bricks and covered with cement-fiber tiles.

Broiler litters were obtained from three different commercial broiler houses from a farm located in Capivari, SP, Brazil. One house was equipped with conventional environmental control system and litter was used for only one flock, and the houses two and three were dark houses and the same litter was used for two and three flocks, respectively. All broiler flocks were reared until 42 days of age, and litter substrate was sawdust.

The commercial broiler houses from which litter was collected were divided in six quadrants and $94 \mathrm{~kg}$ of litter was removed from the geometric center of each quadrant, totaling $560 \mathrm{~kg}$ of litter collected per house. The collected litter from each house was homogenized and distributed in two experimental broiler houses (280 kg each).

A completely randomized experimental design in a $2 \times 3$ factorial arrangement was applied, with two different litter dispositions for composting (piled - P or spread $-\mathrm{S})$ and three different litter utilization times (1, 2, or 3 flocks).

Six samples were collected from each experimental house for the analyses of total nitrogen content, humidity, $\mathrm{pH}$, and microbiological status before fermentation. These samples were considered treatment replicates, and each parameter was individually analyzed.

Litter from the same grow-out (one, two or three) was distributed in two experimental houses, where it 
was either piled (Treatment P) or spread (Treatment S), allowing the simultaneous analysis of litters reutilized for different grow-outs.

The first methodology was composting in piles in the center of the house. The piles were $2.25 \mathrm{~m}$ long, $0.80 \mathrm{~m}$ wide and $0.60 \mathrm{~m}$ high (Treatment $\mathrm{P}$ ). The second methodology was to spread the litter throughout the experimental house at $20 \mathrm{~cm}$ height (Treatment S). It is known that the differences in litter arrangement may affect the speed of the composting process due to changes in aeration and temperature inside piles.

In both treatments, humidity was homogenized in $50-55 \%$ and the litter was aerated every three days, being stirred with the aid of a hoe, which objective was to maintain biological activity by keeping the desired temperature of $60-80^{\circ} \mathrm{C}$. The disposition of the litter in the experimental house (pile and spread) as well as litter fermentation for 12 days, were chosen to simulate the litter management practice commonly applied in commercial broiler houses during downtime between broiler flocks. Both methodologies are adapted from Silva et al. (2007).

During composting, litter humidity, gas emission $\left(\mathrm{NH}_{3}\right.$ and $\left.\mathrm{CO}_{2}\right)$, environmental temperature, air relative humidity, and air velocity were determined in the experimental houses. After the composting period, these parameters were analyzed to compare the periods before and after fermentation.

Data were submitted to the F-test to verify the equality of variances, and means were compared by the $T$ test $(p<0.05)$.

\section{RESULTS AND DISCUSSION}

Table 1 presents mean and standard deviation values of nitrogen, humidity and $\mathrm{pH}$ of the litters used for one, two or three flocks compared with the values obtained before and after composting. Piling significantly reduced total nitrogen percentage and increased $\mathrm{pH}$ and humidity $(p<0.05)$ when litter had been used once

Table 1. Litter parameter obtained before and after being submitted to the different composting treatments.

\begin{tabular}{|c|c|c|c|c|c|c|c|c|c|}
\hline \multirow{4}{*}{ Method } & \multicolumn{9}{|c|}{ Parameters } \\
\hline & \multicolumn{9}{|c|}{ Litter used once } \\
\hline & Before & After & & Before & After & & Before & After & \\
\hline & $\begin{array}{c}\text { Mean } \\
\text { (standard } \\
\text { deviation) }\end{array}$ & $\begin{array}{c}\text { Mean } \\
\text { (standard } \\
\text { deviation) }\end{array}$ & $P$ value & $\begin{array}{c}\text { Mean } \\
\text { (standard } \\
\text { deviation) }\end{array}$ & $\begin{array}{c}\text { Mean } \\
\text { (standard } \\
\text { deviation) }\end{array}$ & $P$ value & $\begin{array}{c}\text { Mean } \\
\text { (standard } \\
\text { deviation) }\end{array}$ & $\begin{array}{c}\text { Mean } \\
\text { (standard } \\
\text { deviation) }\end{array}$ & $P$ value \\
\hline \multirow[b]{2}{*}{$\mathrm{P}$} & \multicolumn{3}{|c|}{ Nitrogen (\%) } & \multicolumn{3}{|c|}{ Humidity (\%) } & \multicolumn{3}{|c|}{$\mathrm{pH}$} \\
\hline & $\begin{array}{c}1.49 \\
(0.0031) a\end{array}$ & $0.66(0.0002) b$ & 0.0013 & $\begin{array}{c}15.71 \\
(0.0100) a\end{array}$ & $42.92(0.0244) b$ & 0.0000 & $\begin{array}{c}8.25 \\
(0.0757) a\end{array}$ & $8.90(0.0486) b$ & 0.0000 \\
\hline $\mathrm{S}$ & $\begin{array}{c}2.46 \\
(0.0027) a\end{array}$ & $0.68(0.0006) a$ & 0.0000 & $\begin{array}{c}15.00 \\
(0.0174) a\end{array}$ & $38.00(17.733) b$ & 0.0000 & $\begin{array}{c}7.80 \\
(0.2490) a\end{array}$ & $8.88(0.0509) b$ & 0.0003 \\
\hline \multirow{5}{*}{ Method } & \multicolumn{9}{|c|}{ Parameters } \\
\hline & \multicolumn{9}{|c|}{ Litter used for two grow-outs } \\
\hline & Before & After & & Before & After & & Before & After & \\
\hline & $\begin{array}{c}\text { Mean } \\
\text { (standard } \\
\text { deviation) }\end{array}$ & $\begin{array}{c}\text { Mean } \\
\text { (standard } \\
\text { deviation) }\end{array}$ & $P$ value & $\begin{array}{c}\text { Mean } \\
\text { (standard } \\
\text { deviation) }\end{array}$ & $\begin{array}{c}\text { Mean } \\
\text { (standard } \\
\text { deviation) }\end{array}$ & $P$ value & $\begin{array}{c}\text { Mean } \\
\text { (standard } \\
\text { deviation) }\end{array}$ & $\begin{array}{c}\text { Mean } \\
\text { (standard } \\
\text { deviation) }\end{array}$ & P value \\
\hline & \multicolumn{3}{|c|}{ Nitrogen (\%) } & \multicolumn{3}{|c|}{ Humidity (\%) } & \multicolumn{3}{|c|}{$\mathrm{pH}$} \\
\hline $\mathrm{P}$ & $\begin{array}{c}1.69 \\
(0.0018) a\end{array}$ & $0.85(0.0003) b$ & 0.0001 & $\begin{array}{c}13.72 \\
(0.0152) a\end{array}$ & $41.44(0.0100) b$ & 0.0000 & $\begin{array}{c}8.01 \\
(0.2422) a\end{array}$ & $8.89(0.0376) b$ & 0.0005 \\
\hline $\mathrm{S}$ & $\begin{array}{c}2.36 \\
(0.0057) a\end{array}$ & $0.75(0.0003) b$ & 0.0010 & $\begin{array}{c}13.21 \\
(0.0050) a\end{array}$ & $42.45(0.0279) b$ & 0.0000 & $\begin{array}{c}7.92 \\
(0.2661) a\end{array}$ & $8.80(0.0234) b$ & 0.0005 \\
\hline \multirow{5}{*}{ Method } & \multicolumn{9}{|c|}{ Parameters } \\
\hline & \multicolumn{9}{|c|}{ Litter used for three grow-outs } \\
\hline & Before & After & & Before & After & & Before & After & \\
\hline & $\begin{array}{c}\text { Mean } \\
\text { (standard } \\
\text { deviation) }\end{array}$ & $\begin{array}{c}\text { Mean } \\
\text { (standard } \\
\text { deviation) }\end{array}$ & $P$ value & $\begin{array}{c}\text { Mean } \\
\text { (standard } \\
\text { deviation) }\end{array}$ & $\begin{array}{c}\text { Mean } \\
\text { (standard } \\
\text { deviation) }\end{array}$ & $P$ value & $\begin{array}{c}\text { Mean } \\
\text { (standard } \\
\text { deviation) }\end{array}$ & $\begin{array}{c}\text { Mean } \\
\text { (standard } \\
\text { deviation) }\end{array}$ & $P$ value \\
\hline & \multicolumn{3}{|c|}{ Nitrogen (\%) } & \multicolumn{3}{|c|}{ Humidity (\%) } & \multicolumn{3}{|c|}{$\mathrm{pH}$} \\
\hline$P$ & $\begin{array}{c}1.35 \\
(0.0016) a\end{array}$ & $0.61(0.0002) a$ & 0.0000 & $\begin{array}{c}16.12 \\
(0.0078) a\end{array}$ & $19.00(0.0434) b$ & 0.0000 & $\begin{array}{c}8.38 \\
(0.0349) a\end{array}$ & $8.89(0.0417) b$ & 0.0000 \\
\hline$S$ & $\begin{array}{c}1.48 \\
(0.0024) a\end{array}$ & $0.65(0.0002) b$ & 0.0004 & $\begin{array}{c}14.12 \\
(0.0103) a\end{array}$ & $38.24(0.0450) b$ & 0.0000 & $\begin{array}{c}8.04 \\
(0.2194) a\end{array}$ & $8.87(0.0242) b$ & 0.0003 \\
\hline
\end{tabular}

Legend: P Piled; S: Spread

Means followed by the same letter in the same row are statistically similar by the T test $(P<0.05)$. 
and twice. When the litter was used for three growouts, humidity and $\mathrm{pH}$ also increased, but total nitrogen level remained similar (Table 1). This behaviour can be explained by how the substrate was arranged, because when the litter is piled, the microenvironment is kept constant, resulting in optimal temperatures for the fermentation process. When litter was spread (Table 1), $\mathrm{pH}$ and humidity increased $(\mathrm{p}<0.05)$, while nitrogen levels were not different before and after treatment when the litter had been used only once and were reduced when litter had been used for two and three grow-outs. As the exposed surface of the spread litter was larger, it is possible that the nitrogen released was able to be captured more rapidly by the sensors.

According to Orrico Jr. et al. (2009), adequate temperature $\left(>50^{\circ} \mathrm{C}\right)$ and humidity between 40 and $60 \%$ are required to allow bacterial fermentation during composting. After fermentation, organic matter biodegradable solids remain stable, and the compost can be then managed, stored, and used as organic fertilizer with no negative effects on the environment if the correct dose is applied.

Table 2 presents mean and standard deviation of the counts of the main microorganisms found in the three different litters before and after composting ( $\mathrm{P}$ or S). Total bacteria and Salmonella sp counts before and after fermentation were not different ( $p>0.05)$ among litters used for one, two or three grow-outs in none of the treatments (P or S), as shown in Table 2. On the other hand, fungal counts were reduced only when litters used two and three times were spread.

According to Oliveira et al. (2003), higher litter humidity promotes higher activity of ammoniaproducing bacteria, consequently increasing substrate pH. Nitrogen losses, according to Orrico Jr. et al. (2004), are caused by an imbalance in the carbon:nitrogen ratio in the substrate, and nitrogen is then lost by volatilization as ammonia. Ammonia $\left(\mathrm{NH}_{4}^{+} \cdot-\mathrm{N}\right)$ is produced by microorganisms that hydrolyze nitrogen compounds, a process called ammonification. The

Table 2. Microbial counts in the litter obtained before and after being submitted to the different composting treatments.

\begin{tabular}{|c|c|c|c|c|c|c|c|c|c|}
\hline \multirow{4}{*}{ Method } & \multicolumn{9}{|c|}{ Parameters } \\
\hline & \multicolumn{9}{|c|}{ Litter used for one grow-out } \\
\hline & Before & After & & Before & After & & Before & After & \\
\hline & $\begin{array}{c}\text { Mean } \\
\text { (standard } \\
\text { deviation) }\end{array}$ & $\begin{array}{c}\text { Mean } \\
\text { (standard } \\
\text { deviation) }\end{array}$ & $P$ value & $\begin{array}{c}\text { Mean } \\
\text { (standard } \\
\text { deviation) }\end{array}$ & $\begin{array}{c}\text { Mean } \\
\text { (standard } \\
\text { deviation) }\end{array}$ & $P$ value & $\begin{array}{c}\text { Mean } \\
\text { (standard } \\
\text { deviation) }\end{array}$ & $\begin{array}{c}\text { Mean } \\
\text { (standard } \\
\text { deviation) }\end{array}$ & $P$ value \\
\hline \multirow[b]{2}{*}{$P$} & \multicolumn{3}{|c|}{ Total bacteria (CFU/g) } & \multicolumn{3}{|c|}{ Salmonella sp (CFU/g) } & \multicolumn{3}{|c|}{ Fungi (CFU/g) } \\
\hline & $\begin{array}{c}663.83 \\
(247.62) a\end{array}$ & $812.17(606.42) a$ & 0.5913 & $\begin{array}{c}13267.17 \\
(4952.45) a\end{array}$ & $\begin{array}{c}16233.83 \\
(12129.25) a\end{array}$ & 0.5913 & $\begin{array}{c}2733.83 \\
(1636.66) a\end{array}$ & $\begin{array}{c}1433.83 \\
(163.30) a\end{array}$ & 0.1736 \\
\hline $\mathrm{S}$ & $\begin{array}{c}681.33 \\
(531.72) a\end{array}$ & 304.67 (41.88)a & 0.1442 & $\begin{array}{c}13617.17 \\
(10634.36) a\end{array}$ & $\begin{array}{c}6083.83 \\
(837.66) a\end{array}$ & 0.5913 & $\begin{array}{c}2733.83 \\
(1887.50) a\end{array}$ & $\begin{array}{c}1433.83 \\
(991.30) a\end{array}$ & 0.1736 \\
\hline \multirow{5}{*}{ Method } & \multicolumn{9}{|c|}{ Parameters } \\
\hline & \multicolumn{9}{|c|}{ Litter used for two grow-outs } \\
\hline & Before & After & & Before & After & & Before & After & \\
\hline & $\begin{array}{c}\text { Mean } \\
\text { (standard } \\
\text { deviation) }\end{array}$ & $\begin{array}{c}\text { Mean } \\
\text { (standard } \\
\text { deviation) }\end{array}$ & $P$ value & $\begin{array}{c}\text { Mean } \\
\text { (standard } \\
\text { deviation) }\end{array}$ & $\begin{array}{c}\text { Mean } \\
\text { (standard } \\
\text { deviation) }\end{array}$ & $P$ value & $\begin{array}{c}\text { Mean } \\
\text { (standard } \\
\text { deviation) }\end{array}$ & $\begin{array}{c}\text { Mean } \\
\text { (standard } \\
\text { deviation) }\end{array}$ & $P$ value \\
\hline & \multicolumn{3}{|c|}{ Total bacteria (CFU/g) } & \multicolumn{3}{|c|}{ Salmonella sp (CFU/g) } & \multicolumn{3}{|c|}{ Fungi (CFU/g) } \\
\hline S & $\begin{array}{l}277.17 a \\
(215.80)\end{array}$ & 839.67 (606.26)a & 0.0579 & $\begin{array}{c}5533.83 \\
(4315.86) a\end{array}$ & $\begin{array}{c}16783.83 \\
(12125.25) a\end{array}$ & 0.0579 & $\begin{array}{c}15800.50 \\
(17558.13) a\end{array}$ & $\begin{array}{c}600.50 \\
(1027.62) a\end{array}$ & 0.0879 \\
\hline $\mathrm{S}$ & $\begin{array}{c}424.67 \\
(572.34) a \\
\end{array}$ & 279.67 (127.96)a & 0.5712 & $\begin{array}{c}8483.83 \\
(11446.82) a \\
\end{array}$ & $\begin{array}{c}5583.83 \\
(2559.23) a\end{array}$ & 0.5712 & $\begin{array}{c}1933.83 \\
(1121.90) a\end{array}$ & $\begin{array}{c}733.83(588.78) \\
b\end{array}$ & 0.0428 \\
\hline \multirow{5}{*}{ Method } & \multicolumn{9}{|c|}{ Parameters } \\
\hline & \multicolumn{9}{|c|}{ Litter used for three grow-outs } \\
\hline & Before & After & & Before & After & & Before & After & \\
\hline & $\begin{array}{c}\text { Mean } \\
\text { (standard } \\
\text { deviation) }\end{array}$ & $\begin{array}{c}\text { Mean } \\
\text { (standard } \\
\text { deviation) }\end{array}$ & $P$ value & $\begin{array}{c}\text { Mean } \\
\text { (standard } \\
\text { deviation) }\end{array}$ & $\begin{array}{c}\text { Mean } \\
\text { (standard } \\
\text { deviation) }\end{array}$ & P value & $\begin{array}{c}\text { Mean } \\
\text { (standard } \\
\text { deviation) }\end{array}$ & $\begin{array}{c}\text { Mean } \\
\text { (standard } \\
\text { deviation) }\end{array}$ & $P$ value \\
\hline & \multicolumn{3}{|c|}{ Total bacteria (CFU/g) } & \multicolumn{3}{|c|}{ Salmonella sp (CFU/g) } & \multicolumn{3}{|c|}{ Fungi (CFU/g) } \\
\hline$P$ & $\begin{array}{c}872.17 \\
(232.22) \mathrm{a}\end{array}$ & 659.67 (195.71)a & 0.1173 & $\begin{array}{c}17433.83 \\
(4644.42) \mathrm{a}\end{array}$ & $\begin{array}{c}13183.83 \\
(3914.29) a\end{array}$ & 0.1173 & $\begin{array}{c}13933.83 \\
(6826.61) a\end{array}$ & $0.50(0.0000) b$ & 0.0041 \\
\hline $\mathrm{S}$ & $\begin{array}{c}739.67 \\
(497.71) a\end{array}$ & 545.50 (379.09)a & 0.4647 & $\begin{array}{c}14783.83 \\
(9954.18) a\end{array}$ & $\begin{array}{c}10900.50 \\
(7581.82) \mathrm{b}\end{array}$ & 0.4657 & $\begin{array}{c}6200.50 \\
(4705.74) b\end{array}$ & 133.83 (326.57)a & 0.0254 \\
\hline
\end{tabular}

Legend: P Piled; S: Spread

Means followed by the same letter in the same row are statistically similar by the T test $(P<0.05)$. 
$\mathrm{NH}_{4}^{+}$- $-\mathrm{N}$ produced is used either for microbial growth or for nitrification, which is the conversion of ammonia in nitrates. When there is more nitrogen than the microorganisms are capable of assimilating, it is lost in the atmosphere as nitrogen oxide and ammonia, which represents the larger fraction of nitrogen losses. Tiquia \& Tam (2000) asserted that pH is one of the main factors influencing $\mathrm{N}$ losses, because alkalinity favor ammonia formation, leading to further reduction in $\mathrm{N}$ content in the compost. In the present study, $\mathrm{pH}$ was maintained higher than 8.6, therefore favoring the formation of ammonia.

Costa et al. (2006) studied N concentrations during composting of dead broilers using different aeration systems, and obtained $3.85 \%$ at the start and $2.45 \%$ at the end of the process. Tiquia \& Tam (2000), when composting broiler house waste, observed a $50 \%$ reduction in $\mathrm{NH}_{4}^{+}$- $-\mathrm{N}$ between days 1 and 7 of composting, and stable ammonia concentrations only after day 35 . Those authors also determined a $59 \% \mathrm{~N}$ reduction in the mass relative to the initial $\mathrm{N}$ content and attributed these nitrogen losses to the low C/N ratio of the material, high temperature of the piles, and $\mathrm{pH}$ higher than 7.

Orrico Jr. et al. (2010) evaluated the efficiency of composting for the treatment and recycling of broiler litter and broiler carcasses using as parameters total and heat-tolerant coliform counts, total solids, temperature, $\mathrm{pH}$ and $\mathrm{N}, \mathrm{P}, \mathrm{K}, \mathrm{Ca}, \mathrm{Na}, \mathrm{Mg}, \mathrm{Fe}, \mathrm{Zn}$, and Cu contents. The authors observed significant reduction in total solids and particularly in nitrogen, which accounted for $71.6 \%$ of the losses during composting. In that study, there was $100 \%$ reduction in the presence of total and heat-resistant coliform counts, possibly due to the longer fermentation period of 60 days.

The thermophilic phase is critical to reduce pathogens in waste. In the study of Costa et al. (2006) on the composting of broiler carcasses, there was a progressive reduction in total and thermotolerant coliforms, as well as elimination of bacteria of the genus Salmonella, which were isolated from the initial material and were no longer detected in the final compost.

In their study, Orrico Jr. et al. (2010) found that composting was efficient to eliminate total thermotolerant coliforms during the piling period, which was not found in the present study. Those authors observed $100 \%$ reduction, with numbers of $1.1 \times 10^{8} \mathrm{NMP} \mathrm{g}^{-1}$ in the beginning and $0 \mathrm{NMP} \mathrm{g}^{-1}$ at the end of composting for total and thermotolerant coliforms. Other studies, such as those of Curci et al. (2007), Torres et al. (2007), and Orrico et al. (2007), also observed that composting was efficient to eliminate pathogenic microorganisms. The maintenance of bacterial counts in the present study may have been due to shorter fermentation time, favoring further nitrogen reduction.

The reduction of pathogen counts in the final product of litter composting that will be utilized again in the broiler house has extreme importance. As well as the high coliform counts in drinking water, this factor may result in higher incidence of diseases, and consequent increase in mortality and production losses (Salminen \& Rintala, 2002).

\section{CONCLUSIONS}

Based on the obtained results, it is concluded that neither of the composting methods (piled or spread) significantly reduced bacterial populations, particularly of Salmonella spp., in litters used for one, two or three broiler grow-outs. However, piling the litter was more effective in reducing its $\mathrm{N}$ content, humidity and $\mathrm{pH}$. In addition, the period of 12 days of composting seemed not be sufficient to reduce litter microbial populations. When carrying out studies on different composting methods to treat litter used for different number of broiler grow-outs, longer fermentation times and substrate humidity control are suggested.

\section{ACKNOWLEDGEMENTS}

The authors thank CNPq for the M.Sc. scholarship of the corresponding author, and Fapesp for funding this study.

\section{REFERENCES}

Abreu VMN, Abreu GP, Coldebella A, Jaenisch FGF, Silva VS. Evaluation of material and ventilation systems in poultry production: I. overall performance. Revista Brasileira de Zootecnia 2011; 40(6):1364-1371.

Bilgili SF, Hess JB, Blake JP, Macklin Ks, Saenmahayak B, Sibley JL. Influence of bedding material on footpad dermatitis in broiler chickens. Poultry Science 2009;18(1):583-589.

Bolan NS, Szogl AA, Chuavasathi T, Seshadri B, Rothrock JRMJ, Panneerselvam $P$. Uses and management of poultry litter. Poultry Science 2010;66(12):673-698.

Chernaki-Leffer AM, Biesdorf SM, Almeida LM, Leffer EVB, Vigne F. Isolamento de enterobactérias em Alphitobius diaperinus e na cama de aviários no oeste do Estado do Paraná, Brasil. Revista Brasileira de Ciência Avícola 2002;4(3):243-247.

Costa MSSM, Costa LAM, Pelá A, Silva ACJ, Decarli LD, Matter UF Desempenho de quatro sistemas para compostagem de carcaça de aves. Revista Brasileira de Engenharia Agrícola Ambiental 2006; 10(3):692-698.

Costa MSSM, Costa LAM, Sestak M, Olibone D, Sestak D, Kaufmann AV, Rotta SR. Compostagem de resíduos da indústria de desfibrilação de algodão. Engenharia Agrícola 2005;25(2):540-548. 
Curci VCLM, Dutra IS, Dobereiner J, Lucas Júnior J. Pré-compostagem de cadáveres de bovinos acometidos pelo botulismo. Pesquisa Veterinária Brasileira 2007;27(4):157-161.

Dao TH, Zhang H. Rapid composition and source screening of heterogeneous poultry litter by energy dispersive $x$-ray fluorescence spectrometry. Annals of Environmental Science 2007;1:69-79.

Delaune PB, Moore PA, Daniel TC, Lemunyon JL. Effect chemical and microbial amendments on ammonia volatilization from composting poultry litter. Journal of Environmental Quality 2004;33: 728-734.

Edwards DR, Daniel TC. Environmental impacts of on-farm poultry waste disposal - a review. Bioresource Technology 1992;41(1, p. 9-33, 1992.

Ginting D, Kessavalou A, Eghball B, Doran JW. Greenhouse gas emissions and soil indicators four years after manure and composta applications. Journal of Environment Quality 2003;32:23-32.

Hao X, Chang C, Larney FJ. Carbon, nitrogen balances and greenhouse gas emissioan during cattle feedlot manure composting. Journal of Environment Quality 2004;33:37-44.

Jacob JP, Kunkle WE, Tervola RS, Miles RD, Mather FB. Broiler Litter, Part 1: A feed ingredient for ruminants. Gainsneville: University of Florida Cooperative Extension Service; 1997.

Kelleher BP, Leahy JJ, Henihan AM, O'dwyer TF, Sutton D, Leahy MJ. Advances in poultry litter disposal technology - a review. Bioresource Technology 2002;83(1):27-36.

Kwak WS, Huhb JW, Mccaskey, TA. Effect of processing time on enteric bacteria survival and on temperature and chemical composition of broiler poultry litter processed by two methods. Bioresource Technology 2005;9:1529-1536.

Miller FC. Composting of municipal solid waste and ist components. In: Palmisano AC, Barlaz MA, editor. Microbiology of solid waste. Boca raton: CRC Press; 1996. p.115-154.

Oliveira MC, Almeida CV, Andrade DO, Rodrigues SMM. Teor de matéria seca, $\mathrm{pH}$ e amônia volatilizada da cama de frango tratada ou não com diferentes aditivos. Revista Brasileira de Zootecnia 2003;32(4):951-954.

Oliveira MC, Gourlart RB, Silva JCN. Efeito de duas densidades e dois tipos de cama sobre a umidade da cama e a incidência de lesões na carcaça de frangos de corte. Ciência Animal Brasileira 2002;3(2): 7-12.

Orrico ACA, Lucas Júnior J, Orrico Júnior MAP. Caracterização e biodigestão anaeróbia dos dejetos de caprinos. Engenharia Agrícola 2007;27(3):639-647.

Orrico Júnior MAP, Amorim AC, Lucas Júnior J. Perda de nitrogênio e redução de carbono orgânico durante o processo de compostagem dos resíduos gerados na avicultura de corte. Anais 41 Reunião Anual Da Sociedade Brasileira De Zootecnia; 2004; Campo Grande, Mato Grosso do Sul. Brasil.

Orrico Júnior MAP, Orrico ACA, Lucas Júnior J. Compostagem da fração sólida da água residuária de suinocultura. Engenharia Agrícola 2009;29(3):483-491.

Orrico Junior MAP, Orrico ACA, Lucas Junior J. Compostagem dos resíduos da produção avícola: cama de frangos e carcaças de aves. Engenharia Agrícola 2010;30(3):538-545

Peigne J, Girardin P. Environmental impacts on farm scale composting practices. Water, Air and Soil Pollution 2004;153(1):45-68.

Salminen E, Rintala J. Anaerobic digestion of organic solid poultry slaughterhouse waste - a review. Bioresource Technology 2002;83(1):13-26.
Sharpe RR, Schomberg HH, Harper LA, Endale DM, Jenkins MB, Franzluebbers AJ. Atmospheric pollutants and trace gases. Journal of Environment Quality 2004;33:1183-1188

Silva VS, Voss D, Coldebella A, Avila VS. Efeito de tratamentos sobre a carga bacteriana de cama de aviário reutilizada em frangos de corte [comunicado técnico]. Concórdia: Embrapa Suínos e Aves,; 2007.

Sorbara JOB, Rizzo MF, Laurentiz AC, Schocken-Iturrino RP, Berchielli TT, Moraes VMB. Avaliação da polpa de citros peletizada como material para cama de frangos de corte. Revista Brasileira de Ciência Avícola 2000;2(3):273-280

Sundberg C, Smaars S, Jönsson H. Low pH as an inhibiting factor in the transition from mesophilic to thermophilic phase in composting. Bioresource Technology 2004;95:145-150.

Tiquia Sm, Richard Tl, Honeyman Ms. Effects of windrow turning and seasonal temperatures on composting of hog manure from hoop structures. Environmental Technology 2000;21:1037-1046.

Tiquia Sm, Tam Nfy. Characterization and composting of poultry litter in forced-aeration piles. Process Biochemistry 2002;37:869-880.

Tiquia SM, Tam NFY. Elimination of phytotoxitcity during co-composting of spent pig manure, sawdust litter and sludge. Bioresource Technology 1998;65:43-49.

Torres P, Pérez A, Escobar JC, Uribe IU, Imery R. Compostaje de biosólidos de plantas de tratamiento de águas residuales. Engenharia Agrícola 2007;27(1):267-275

Turnell JR, Faulkner RD, Hinch GN. Recent advances in Australian broiler litter utilisation. World's Poultry Science Journal 2007;63:223-231.

Walter L. Manejo da cama de frangos de corte e aspectos microbiológicos no ambiente de produção. Anais do Seminário Internacional Sobre Coccidiose E Qualidade Intestinal; 2000; Campinas, São Paulo. Brasil. Campinas: COCCIFORUM; 2000. p.44-54. 